\title{
Acute Hypertension Activates Mitogen-activated Protein Kinases in Arterial Wall
}

\author{
Qingbo Xu, ${ }^{\star}$ Yusen Liu, ${ }^{*}$ Myriam Gorospe, ${ }^{*}$ Robert Udelsman, ${ }^{\ddagger}$ and Nikki J. Holbrook ${ }^{\star}$ \\ *Section on Gene Expression and Aging, National Institute on Aging, National Institutes of Health, Baltimore, Maryland 21224; \\ and ${ }^{\ddagger}$ Division of Endocrine Surgery, The Johns Hopkins Hospital, Baltimore, Maryland 21287
}

\begin{abstract}
Mitogen-activated protein (MAP) kinases are rapidly activated in cells stimulated with various extracellular signals by dual phosphorylation of tyrosine and threonine residues. They are thought to play a pivotal role in transmitting transmembrane signals required for cell growth and differentiation. Herein we provide evidence that two distinct classes of MAP kinases, the extracellular signal-regulated kinases (ERK) and the c-Jun $\mathrm{NH}_{2}$-terminal kinases (JNK), are transiently activated in rat arteries (aorta, carotid and femoral arteries) in response to an acute elevation in blood pressure induced by either restraint or administration of hypertensive agents (i.e., phenylephrine and angiotensin II). Kinase activation is followed by an increase in c-fos and c-jun gene expression and enhanced activating protein 1 (AP-1) DNA-binding activity. Activation of ERK and JNK could contribute to smooth muscle cell hypertrophy/hyperplasia during arterial remodeling due to frequent and/or persistent elevations in blood pressure. (J. Clin. Invest. 1996. 97:508-514.) Key words: hypertension - MAP kinases - ERK/JNK • transcription factors • artery remodeling
\end{abstract}

\section{Introduction}

Many factors ranging from physical exertion to psychological stress lead to neuroendocrine responses including release of catecholamines into the circulation and activation of the reninangiotensin system resulting in a transient rise in blood pressure (1-3). This process is largely due to enhanced cardiac output and increased resistance of peripheral arterioles $(3,4)$. If the factors are persistent and the process repeated often, the arteriole walls gradually thicken resulting in chronic hypertension (1-5). Large arteries, such as the aorta, coronary and carotid arteries, undergo adaptation or remodeling in response to elevated blood pressure showing medial hypertrophy and/or intimal hyperplasia of the arterial wall (6). The precise mechanisms by which such hemodynamic and/or mechanical stimuli are converted into biochemical signals that lead to quantitative, as well as qualitative, changes in gene expression in smooth muscle cells of artery wall are largely unknown.

MAP kinases comprise a ubiquitious group of serine/threonine kinases that are activated in response to external signals

Address correspondence to Dr. Nikki Holbrook, Section on Gene Expression and Aging, National Institute on Aging, National Institutes of Health, 4940 Eastern Avenue, Baltimore, MD 21224. Phone: 410-558-8197; FAX: 410-558-8335.

Received for publication 19 May 1995 and accepted in revised form 6 October 1995.

The Journal of Clinical Investigation

Volume 97, Number 2, January 1996, 508-514 including growth factors, tumor promoters (7-9), cytokines $(10,11)$, and a variety of stresses including stretch (12-13). At least two distinct subfamilies of MAP kinases exist, the extracellular signal-regulated kinases $(\mathrm{ERK})^{1}$ and the c-Jun $\mathrm{NH}_{2}-$ terminal kinases $(\mathrm{JNK})$ or stress-activated protein kinases (SAPK), which are distinguished by their phosphorylation motif in the kinase domain VIII (14). These kinases are responsible for the activation and phosphorylation of a variety of other regulatory proteins including transcription factors required for the expression of genes involved in cell growth and/or proliferation $(15,16)$.

Most of our knowledge concerning the activation and function of MAP kinases has come from studies on cultured cells. Little is known about their activation in vivo, or their physiologic role or relevance to pathologic conditions in either animals or humans. In the present study, we examined the relationship between blood pressure and MAP kinase (ERK2/ JNK1) activation in the vasculature. We demonstrate that acute hypertension elicited by either restraint or hypertensive agents leads to the rapid activation of both ERK2 and JNK1 MAP kinases in rat arteries. This kinase activation is associated with upregulation of c-fos, c-jun, and junD gene expression and enhanced DNA-binding activity of AP-1 transcription factor complexes.

\section{Methods}

Animals and restraint model. 4-mo-old male Wistar rats were obtained from Hilltop Lab Animals, Inc. (Scottdale, PA), and acclimated in individual cages for one week prior to experimentation. Rats were maintained on a light/dark $(12 / 12 \mathrm{~h})$ cycle at $24^{\circ} \mathrm{C}$ and received food and water ad libitum. All procedures were performed according to protocols approved by National Institute on Aging Committee for use and care of laboratory animals in accordance with guidelines established by the National Institutes of Health. For restraint experiments, individual animals were placed in clear ventilated plexiglass chambers as described previously (17).

Blood pressure measurements. Rats underwent light anesthesia with thiopental $(40 \mathrm{mg} / \mathrm{kg}$ i.m.) followed by insertion of polyethylene catheters via the common femoral artery and vein into the abdominal aorta and inferior vena cava, respectively (17). The aortic catheter was connected to a pressure transducer (COBE, Lakewood, $\mathrm{CO}$ ) and a blood pressure analyzer (Micro-MED, Inc., Louisville, KY). A bolus injection of various agents or saline was administered via the vena cava catheter and blood pressure measurements were made every $30 \mathrm{~s}$ up to $30 \mathrm{~min}$. The doses of the pharmacologic agents were calculated on a microgram per kilogram basis as determined by their ability to produce consistent hypertensive responses without demonstratable side effects (18).

Chronic catheterization procedure and drug administration. Polyethylene catheters were inserted via the common femoral vein into

1. Abbreviations used in this paper: AP-1, activating protein-1; ERK, extracellular signal-regulated kinases; JNK, c-Jun $\mathrm{NH}_{2}$-terminal protein kinase; MAP, mitogen-activated protein. 
the inferior vena cava under thiopental $(40 \mathrm{mg} / \mathrm{kg}$ i.m.) anesthesia (19). The catheters were tunneled through the subcutaneous tissue to exit from the back where they were connected to a swivel device (Rodent Multi-fluid Channel Swivel; Stoelting Co., Wood Dall, IL). This model allows for complete animal mobility so that subsequent experiments could be performed in conscious, unstressed animals. Saline $(0.4 \mathrm{ml})$ was injected through the catheter daily for $3 \mathrm{~d}$ after catheter insertion. Phenylephrine $(140 \mu \mathrm{g} / \mathrm{kg})$, angiotensin II $(2 \mu \mathrm{g} / \mathrm{kg})$ and sodium nitroprusside $(1 \mathrm{mg} / \mathrm{kg}$ ) (Sigma Chemical Co., St. Louis, MO) were administered via the catheter into the vena cava.

RNA extraction and northern analysis. Freshly harvested tissues were homogenized and the RNA extracted using RNA Stat $60^{\mathrm{TM}}$ (Tel-Test "B", Inc., Friendswood, TX). Total RNA (10 $\mu \mathrm{g} / \mathrm{lane})$ was analyzed using $\left[\alpha-{ }^{32} \mathrm{P}\right.$-labeled cDNA probes for specific mRNA species and standard procedures as described previously $(17,19)$.

Protein extractions. For kinase assays, fresh or rapidly thawed tissue was homogenized with a Polytron homogenizer (PT1200; Kinematica AG, Littau, Switzerland) at the number 6 setting for $30 \mathrm{~s}$ (arteries, heart and skeleton muscle) or for $5 \mathrm{~s}$ (other tissues) on ice in buffer A containing $20 \mathrm{mM}$ Hepes (pH 7.4), $50 \mathrm{mM} \beta$-glycerophosphate, $2 \mathrm{mM}$ EGTA, $1 \mathrm{mM}$ DTT, $1 \mathrm{mM} \mathrm{Na} \mathrm{VO}_{4}, 1 \%$ Triton X-100, $10 \%$ Glycerol, $2 \mu \mathrm{M}$ leupeptin, $400 \mu \mathrm{M}$ PMSF, and $10 \mathrm{U} / \mathrm{ml}$ aprotinin. The homogenate was incubated on ice for $15 \mathrm{~min}$, and centrifuged at 17,000 $\mathrm{g}$ for $30 \mathrm{~min}$. The supernatant was harvested and protein concentration was measured with Bio-Rad protein assay reagent (Bio-Rad Laboratories, Richmond, CA). Protein A-Sepharose 4B suspension (Sigma Chemical Co.) was added to the supernatant (100 $\mu \mathrm{l} / \mathrm{ml}$ ) and rotated for $2 \mathrm{~h}$ at $4^{\circ} \mathrm{C}$. After centrifugation at 17,000 $\mathrm{g}$ for $10 \mathrm{~min}$, the supernatant was harvested.

For gel shift analysis, the procedure for protein extraction was similar to that described above except that the buffer contained $20 \mathrm{mM}$ Hepes (pH 7.5), $1.5 \mathrm{mM} \mathrm{MgCl}, 0.2 \mathrm{mM}$ EDTA, $0.4 \mathrm{M} \mathrm{NaCl}, 0.2 \mathrm{mM}$ DTT, 1 mM Pefablock SC (Boehringer Mannheim, Mannheim, Germany) $20 \%$ glycerol and $1 \mu \mathrm{g} / \mathrm{ml}$ leupeptin. The supernatant was used for the assay after protein concentration was measured.

Kinase assays. $1 \mathrm{ml}$ of the supernatant containing $0.5 \mathrm{mg}$ proteins was incubated with $10 \mu \mathrm{l}$ of antibodies against mammalian ERK2 or JNK1 (Santa Cruz Biochem., Santa Cruz, CA) for $2 \mathrm{~h}$ at $4^{\circ} \mathrm{C}$ with rotation. These antibodies have been shown specifically to recognize mammalian $\mathrm{p} 42^{\mathrm{ERK}}$ and $\mathrm{p} 45^{\mathrm{JNK} 1}(20,21$, Liu et al., manuscript submitted for publication). Subsequently, $40 \mu \mathrm{l}$ of protein A-Sepharose 4B suspension was added and the samples further incubated with rotation for $1 \mathrm{~h}$ at $4^{\circ} \mathrm{C}$. The immunocomplexes were precipitated by centrifugation and washed 2 times with the buffer A $(500 \mathrm{mM} \mathrm{LiCl}, 100$
mM Tris, $1 \mathrm{mM}$ DDT, $0.1 \%$ Triton X-100; pH 7.6), B, and C (20 mM Mops, $2 \mathrm{mM}$ EGTA, $10 \mathrm{mM} \mathrm{MgCl} 2,1 \mathrm{mM}$ DDT, $0.1 \%$ Triton X-100; $\mathrm{pH}$ 7.2), respectively.

The activities of ERK2 in the immunocomplexes were measured as described previously $(11,21,22)$. Briefly, the immunocomplexes were incubated with $35 \mu \mathrm{l}$ of the buffer $\mathrm{C}$ supplemented with myelin basic protein (MBP; $6 \mu \mathrm{g}$; Sigma Chemical Co.), $\gamma^{-32} \mathrm{P}$-ATP $(15 \mu \mathrm{Ci})$, $\mathrm{MgCl}_{2}(50 \mathrm{mM})$ and ATP $(30 \mu \mathrm{M})$ for $20 \mathrm{~min}$ at $37^{\circ} \mathrm{C}$ with vortexing every $3 \mathrm{~min}$. To stop the reaction, $15 \mu \mathrm{l}$ of $4 \times$ Laemmli buffer was added and the mixture was boiled for $5 \mathrm{~min}$. Proteins in the kinase reaction were resolved by SDS-PAGE (15\% gel) and subjected to autoradiography.

The assay for JNK1 activity was performed similarly as described above. The substrate used was GST-c-Jun which was produced in $E$. coli and isolated using glutathione Sepharose 4B RediPack Columns (pharmacia Biotech Inc., Piscataway, NJ) according to the manufacturer's protocol. Proteins in the kinase reaction were resolved by SDS-PAGE (12\% gel) and subjected to autoradiography $(11,21,22)$.

Gel mobility shift assays. The procedure used was similar to that described previously (23). In short, $20 \mu \mathrm{g}$ of aortic tissue protein extract was incubated with $0.5 \mathrm{ng}$ of an oligonucleotide containing the AP-1 binding sequence (5'-CGCTTGATGACTCAGCCGGAA-3'; ref. 24) labeled with $\left[\gamma^{-32} \mathrm{P}\right]$ ATP. For competition experiment, a mutant AP-1 oligonucleotide (5'-CGCTTGATGACTTGGCCGGAA$\left.3^{\prime}\right)$ was also used. Reaction buffer contained $10 \mathrm{mM}$ Tris, (pH 7.5) $1 \mathrm{mM}$ DTT, $1 \mathrm{mM}$ EDTA, $50 \mathrm{mM} \mathrm{NaCl}, 5 \%$ glycerol and $1 \mu \mathrm{g}$ poly(dIdC) as a nonspecific competitor. Samples were electrophoresed through a $4 \%$ polyacrylamide gel and exposed to autoradiographic film. Supershift assays were performed using antibodies against Fos or Jun (Santa Cruz Biochem.). The antibodies were added to samples after the initial binding reactions between protein extracts and oligonucleotides were allowed to take place.

Statistical analysis. Analysis of variance (ANOVA) was performed when more than two groups were compared. An unpaired Student's $t$ test was used to assess differences between two groups. A $P$ value $<0.05$ was considered significant.

\section{Results}

Activation of ERK2 and JNK1 in response to acute hypertension. We have shown previously that restraint, a moderate physical stress, results in a rapid elevation in systemic blood

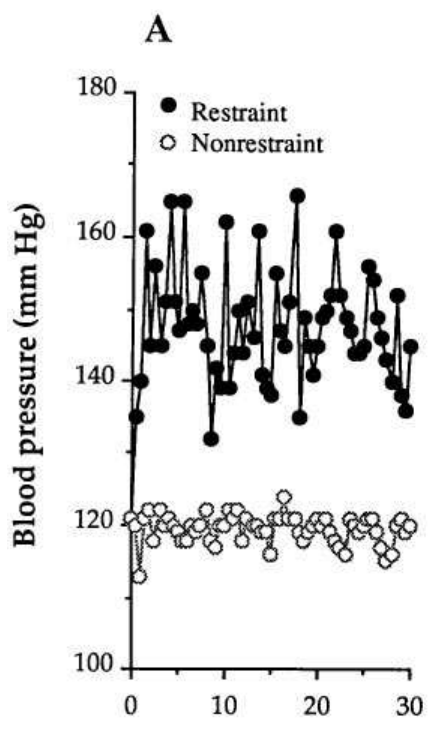

Time (min)
B

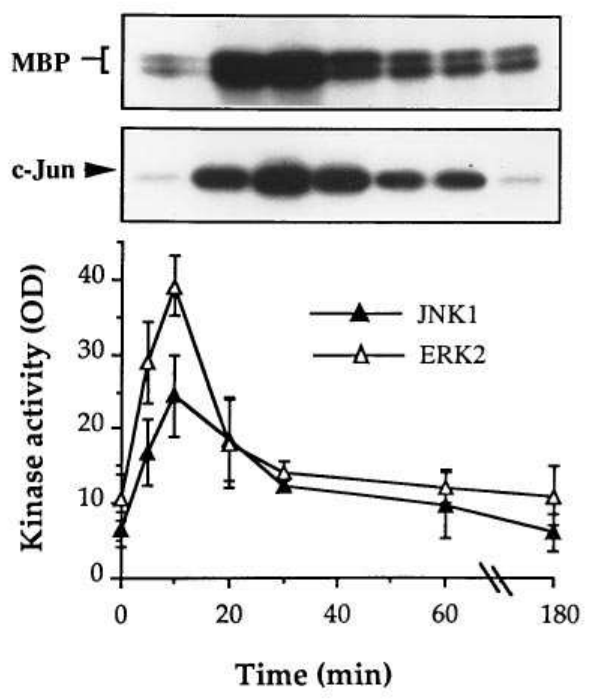

Figure 1. Effect of restraint on blood pressure and ERK2 and JNK1 activities in rat aorta. $(A)$ Arterial systolic blood pressure is increased in rats subjected to restraint. $(B)$ ERK2 and JNK1 kinase activity in aorta of restrained rats. Rats were killed at the indicated time points during or after restraint for up to $30 \mathrm{~min}$. For the 60- and 180-min time points, rats were returned to their cages after restraint. The aorta was freed of adventitia and homogenized. ERK2 and JNK1 proteins were immunoprecipitated from the homogenized preparations and their kinase activities measured based on phosphorylation of myelin basic protein (MBP) or GST-c-Jun fusion protein (c-Jun) substrates, respectively. The upper portion of panel B shows results of a representative experiment examining ERK2 and JNK1 activity at the time points, 0, 5, $10,20,30,60,180 \mathrm{~min}$; the lower portion summarizes the mean $( \pm \mathrm{SD})$ kinase activities obtained in 3 independent experiments. 


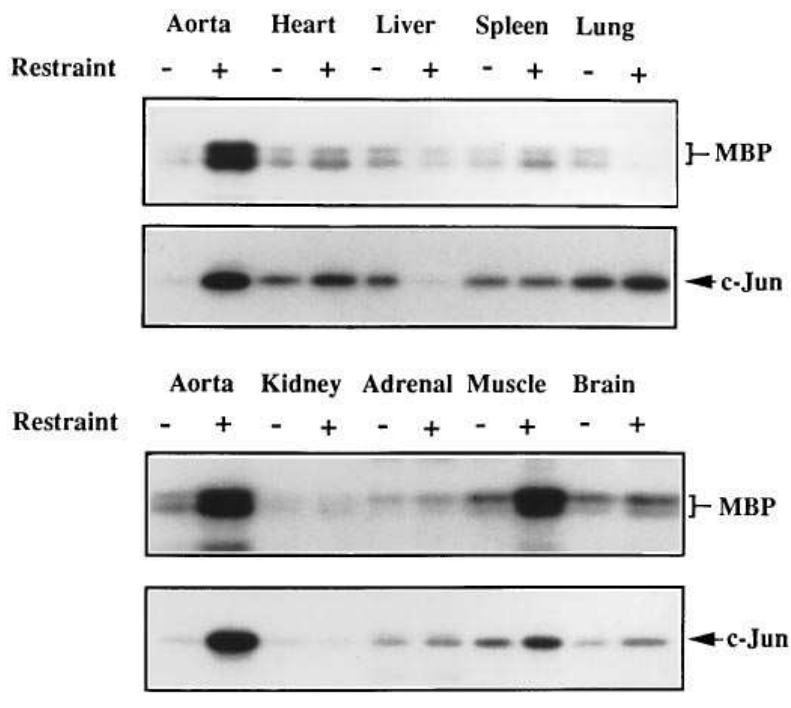

Figure 2. Specificity of ERK2 and JNK1 activation in response to restraint. ERK2 and JNK1 were isolated from the indicated tissues obtained from rats either restrained for $10 \mathrm{~min}(+)$ or left untreated $(-)$. The activities of ERK2 and JNK1 were measured as described in the Methodology.

pressure (18). To determine if this elevation in blood pressure was correlated with the activation of MAP kinases in the vasculature, arterial blood pressure was measured and ERK2 and JNK1 activities were determined after placement of animals in the restraint device for various lengths of time. As shown in Fig. $1 A$, restraint resulted in a rapid rise in systemic blood pressure (systolic, from 120 to $150-160 \mathrm{~mm} \mathrm{Hg}$ ) which was maintained for the entire period of restraint ( $30 \mathrm{~min})$. The effect of this treatment on the kinase activity of ERK2 and JNK1 isolated from rat aorta is shown in Fig. $1 B$. Restraint resulted in the rapid activation of both ERK2 and JNK1 with maximum activity ( $>$ fourfold elevation over those of untreated control) achieved within 5-10 min of restraint. Despite the fact that the blood pressure remained elevated, the kinase activity declined with longer periods of restraint.
Examination of ERK2 and JNK1 activity in other tissues of restrained animals revealed that most of these did not show any significant change in the activity of either ERK2 or JNK1 (Fig. 2). However, activation of ERK2 was observed in skeletal muscle, and a slight activation of JNK1 was seen in lung. The mechanism of the activation in these tissues is unknown, but may reflect the effects of muscle contraction and rapid respiration during restraint stress.

Activation of ERK2 and JNK1 was likewise seen following treatment of rats with hypertensive agents including phenylephrine (see Fig. 5 below) and angiotensin II. Fig. 3 depicts the dose-response relations for angiotensin II-induced acute hypertension and aortic ERK2 and JNK1 activation. As can be seen, blood pressure levels and activities of both kinases increased in parallel as a function of the dose of angiotensin II. Importantly, the activation of these MAP kinases in response to high blood pressure was not restricted to the aorta but also occurred in other vessels including the carotid and femoral arteries (Fig. 4).

Sodium nitroprusside prevents kinase activation. Phenylephrine and angiotensin II interact with distinct receptors $\left(\alpha_{1}\right.$-adrenergic and Angiotensin II receptors, respectively) to exert their effects on systemic blood pressure. Restraintinduced hypertension is also believed to be mediated through $\alpha_{1}$-adrenergic receptors (19). Phenylephrine and angiotensin II have been shown to be effective inducers of ERK activation in cultured muscle cells through receptor-mediated stimulation attributed to growth factor effects (25-27). Therefore, we sought to determine whether the activation we observed in vivo was dependent on changes in blood pressure. The antihypertensive agent sodium nitroprusside, which induces vascular relaxation through release of nitric oxide (NO; reference 28), was used for this purpose. As shown in Fig. $5 A$, administration of sodium nitroprusside alone to rats caused a pronounced decrease in systemic blood pressure. In addition, it prevented the elevation in blood pressure by phenylephrine, angiotensin II, and restraint. Determination of ERK2 and JNK1 activity in similarly treated animals revealed that while sodium nitroprusside treatment alone did not alter the activities of ERK and JNK, it greatly abrogated the activation of both kinases by the hypertensive agents (Fig. 5, $B$ and $C$ ).
A

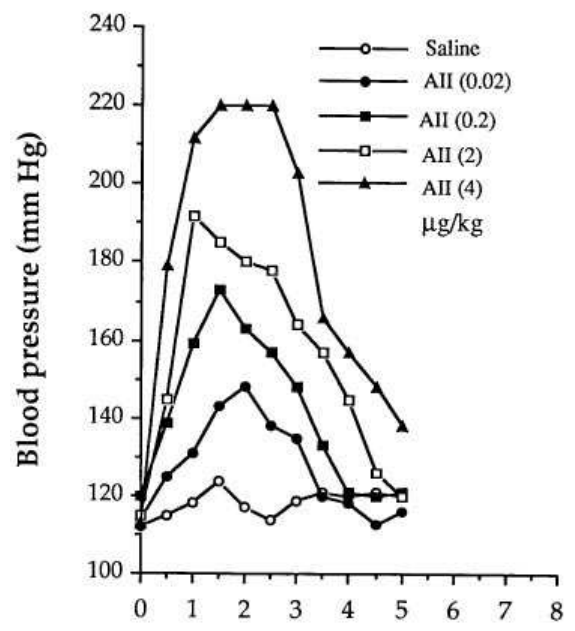

Time (min)
B
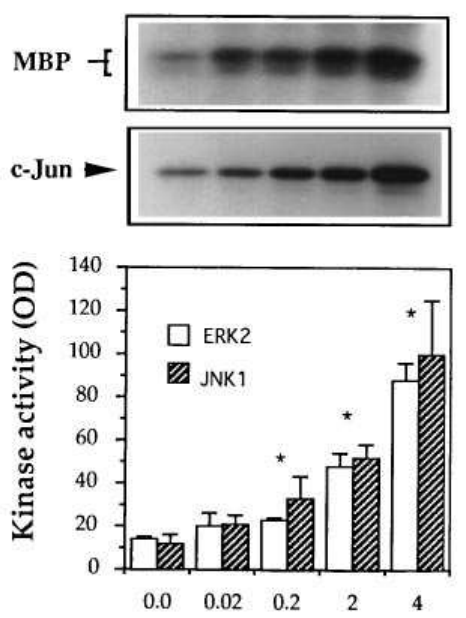

Angiotensin II $(\mu \mathrm{g} / \mathrm{kg})$
Figure 3. Dose-dependent increases in blood pressure and kinase activities with angiotensin II treatment. Rats were killed 5 min after injection of either saline (control) or angiotensin II (i.v.), and aortic protein extracts were prepared for kinase assays. $(A)$ Changes in systolic blood pressure after administration of saline or angiotensin II. $(B)$ The upper portion shows results of a representative experiment examining ERK2 and JNK1 activity at the indicated doses; the lower portion summarizes the mean $( \pm \mathrm{SD})$ kinase activities obtained in two independent experiments. *Significant difference from the control ( 0 ; saline injection). 

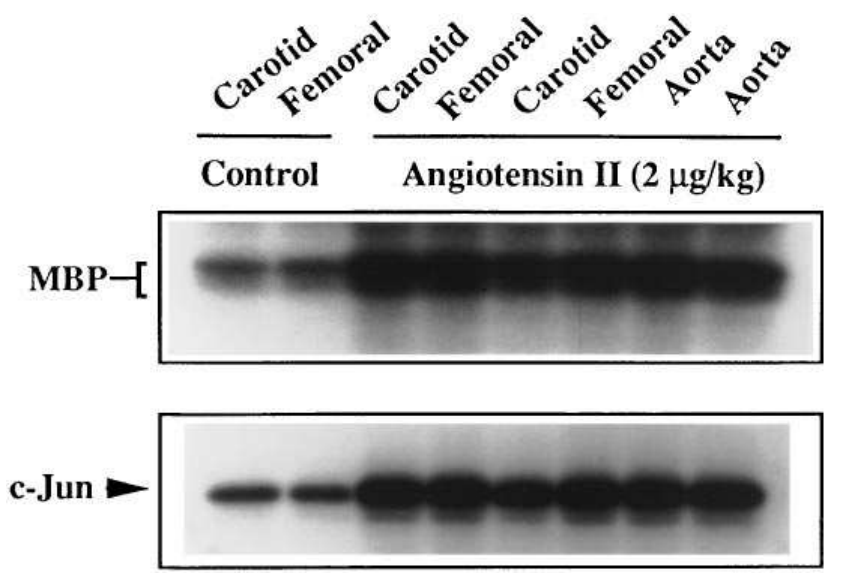

Figure 4. Activation of ERK2 and JNK1 in carotid and femoral arteries of angiotensin II-treatments. Rats were treated with saline or angiotensin II $(2 \mu \mathrm{g} / \mathrm{kg})$, and 5 min post-treatment aorta, carotid, and femoral arteries were prepared for the kinase assays. Data represent ERK2 and JNK1 activities from two or three individual animals per group.

MAP kinase activities during repetitive challenge by phenylephrine. Fluctuations in blood pressure above the normal level are believed to be an early stage of chronic hypertension. In animal models, hypertension can be achieved through the long-term administration of hypertensive agents. To determine if ERK and JNK MAP kinase activities are attenuated by repeated challenge with hypertensive agents, rats were injected daily with phenylephrine up to $1 \mathrm{wk}$. The data shown in

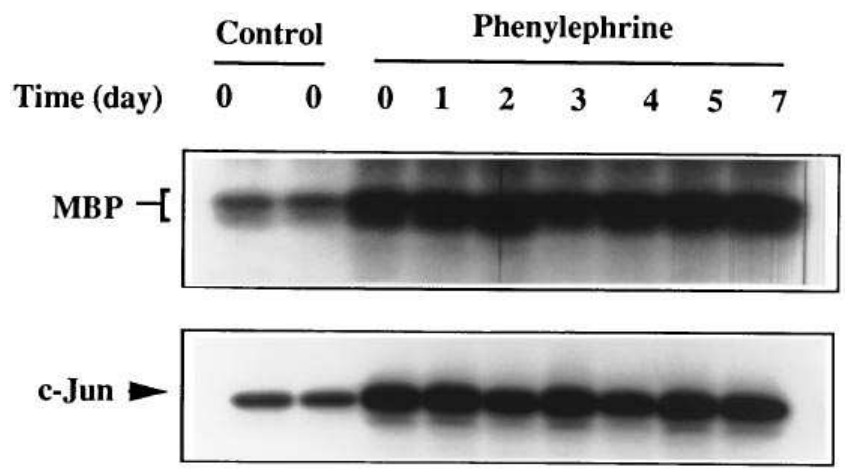

Figure 6. Kinase activities after repeated challenge by phenylephrine. Rats were daily treated with saline or phenylephrine $(140 \mu \mathrm{g} / \mathrm{kg})$ up to $1 \mathrm{wk}$, and $5 \mathrm{~min}$ after injection, aorta was prepared for the kinase assays. Data represent ERK2 and JNK1 activities from day (d) 0 to day 7 .

Fig. 6 demonstrate significant activation of ERK2 and JNK1 at all time points tested. No significant difference in activity of either kinase was found from day 0 to day 7 . That is, the animals did not become sensitized or tolerant to treatment with the hypertensive agent. These results suggest that frequent and/or continued activation of MAP kinases could be responsible for increased gene expression during early stages of chronic hypertension.

c-fos and jun gene expression. Both c-fos and c-jun gene expression have been shown to rely on MAP kinase-dependent phosphorylation of transcription factors including $\mathrm{p} 62^{\mathrm{TCF}}$ and Jun $(29,30)$. Therefore, we examined whether restraint-
A

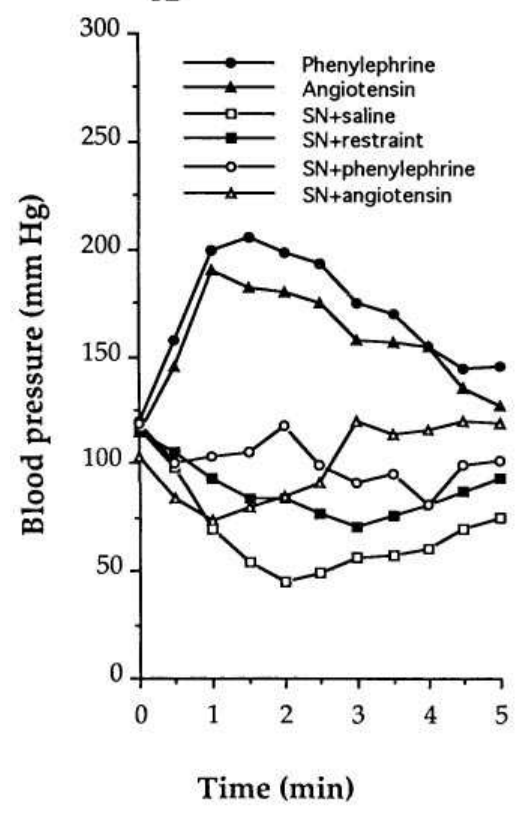

B
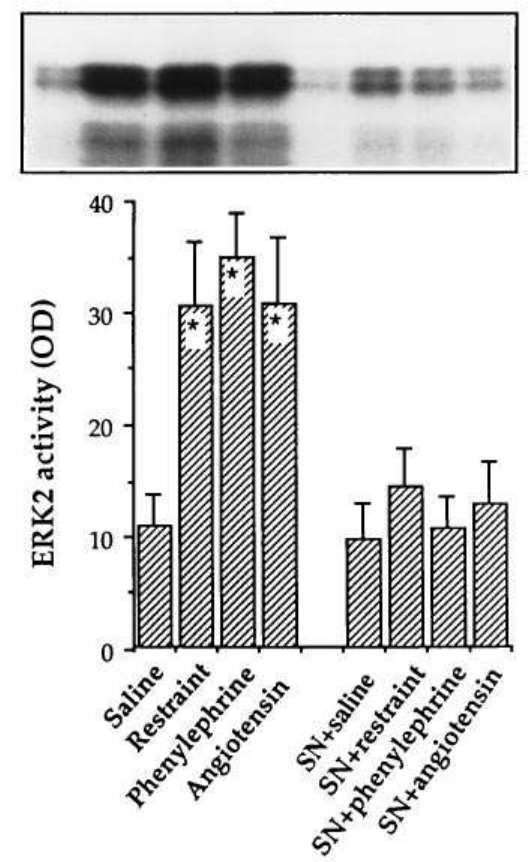

C
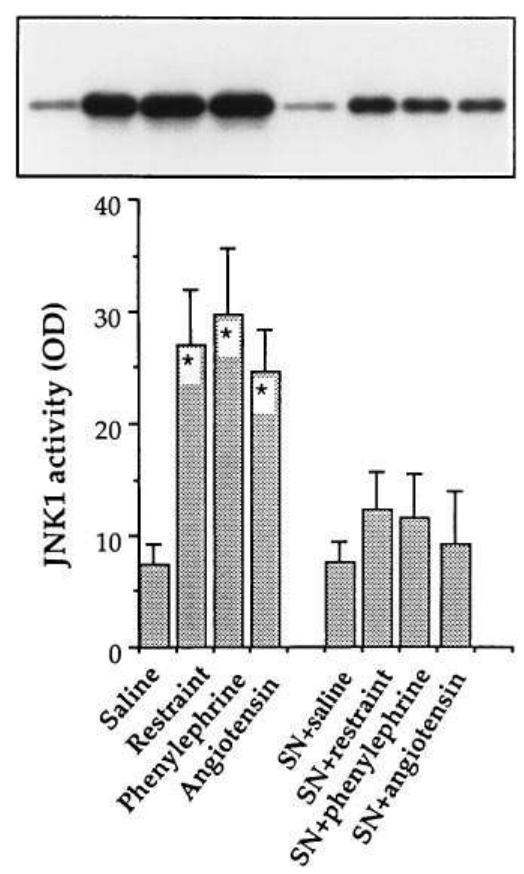

Figure 5. Sodium nitroprusside prevents elevations in blood pressure and abolishes activation of ERK2 and JNK1 in response to restraint and treatment with hypertensive agents. $(A)$ Systolic blood pressure measurements achieved with the various treatments. $(B$ and $C)$ Activities of ERK2 and JNK1. Results shown are the mean activities $( \pm$ SD) for four individual animals examined for each treatment condition. *Significant difference from untreated control $(P<0.01)$. SN, sodium nitroprusside was added immediately prior to restraint, phenylephrine, or angiotensinII treatment. 
Time (h) $\quad \begin{array}{llllll}0 & 0.3 & 0.5 & 1 & 3 & 6\end{array}$

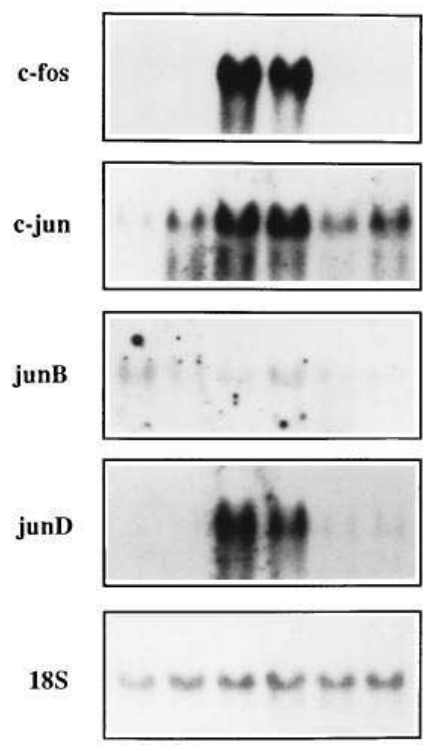

Figure 7. Northern blot analysis of c-fos and jun expression in rat aorta. Total RNA was isolated from aortas of rats restrained for a period of time up to 30 min and killed at the indicated time points. Northern blots $(10 \mu \mathrm{g}$ of RNA per lane) were hybridized sequentially with c-fos, c-jun, junB, or junD

cDNA probes and with an oligonucleotide probe to 18 s rRNA.

induced MAP kinase activation was associated with enhanced expression of these genes. As shown in Fig. 7, both c-fos and c-jun mRNA expression was induced in response to restraint. $j u n D$, a second member of the jun family, also showed increased expression while a third member, junB, did not. The induction was rapid and transient, consistent with the kinetics of activation for ERK2 and JNK1.

AP-1 binding activation. Members of the Fos and Jun protein family dimerize to form AP-1 transcription factor complexes that regulate the expression of other genes $(31,32)$. To determine if AP-1 binding activity was increased in aortas of restrained rats, gel mobility shift assays using an oligonucleotide containing an AP-1 binding site were performed. Fig. $8 \mathrm{~A}$ shows a time course for AP-1 activation in rat aorta in response to restraint. Consistent with our previous studies (23), two regions of binding activity were apparent. The broad slower migrating region designated with a half bracket was found to represent specific binding since it was successfully competed for by cold oligonucleotides corresponding to the AP-1 binding site, but not by a mutated AP-1 oligonucleotide that fails to bind the transcription factor (Fig. $8 \mathrm{~B}$ ). The faster migrating band, designated NS, is presumed to represent nonspecific interaction as this binding activity was present in similar levels in aortic extracts from both treated and untreated animals, and was not affected by the addition of cold AP-1 oligonucleotides. Increased AP-1-binding activity was evident within 20 min of restraint, but maximum DNA-binding was not achieved until $6 \mathrm{~h}$ after restraint.

Fig. $8 \mathrm{~B}$ also shows the results of gel mobility shift assays performed in the presence of antibodies specific to c-Fos or c-Jun proteins. Addition of either antibody to the binding reaction resulted in a shift of the binding complexes to a slow migrating species, indicating the presence of both Fos and Jun proteins in the DNA-binding complexes.

\section{Discussion}

Most of our current knowledge concerning the activities and functions of the ERK and JNK MAP kinases in regulating gene expression has come from in vitro studies using nonphysiologic treatment conditions (7-16). In the present study we have demonstrated the in vivo activation of ERK2 and JNK1 in the arteries of rats following treatments resulting in an acute elevation in blood pressure. That this response occurs with relatively mild increases in blood pressure, akin to those
A

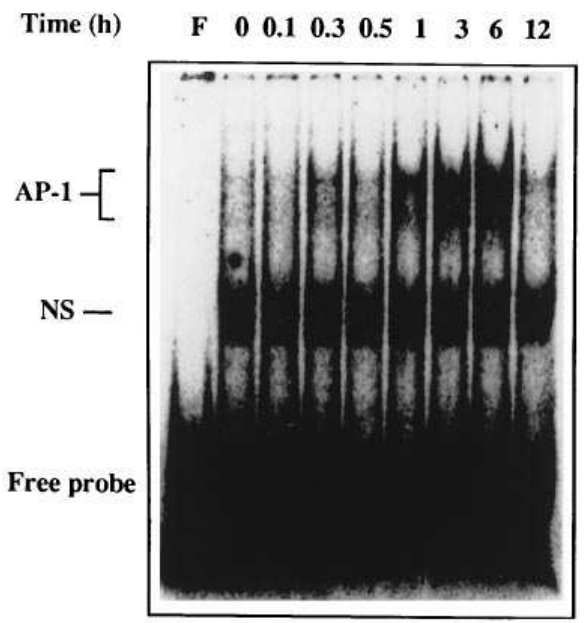

B
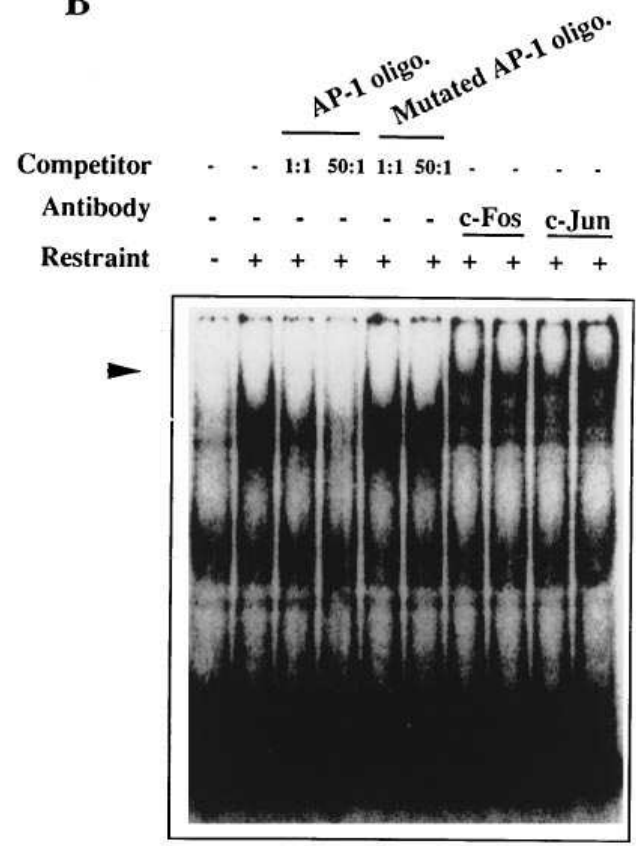

Figure 8. Analysis of AP-1-binding activity in aortic extracts. $(A)$ Gel mobility shift assay performed using whole tissue extracts $(20 \mu \mathrm{g}$ protein per lane) from aortas of unrestrained rats or rats restrained for the indicated time. The bracket indicates specific AP-1-binding complexes; $N S$, nonspecific binding. $(B)$ Extracts obtained from aorta of unrestrained rats or rats restrained for $30 \mathrm{~min}$ and returned to their cages up to $6 \mathrm{~h}$ (two per group) were incubated with a radiolabeled oligonucleotide containing an AP-1 binding site with no addition $(-)$, in the presence of unlabeled AP-1, or unlabeled mutant AP-1, oligonucleotides (1:1 and 50:1); or in the presence of antibodies (1:20) specific to c-Fos or c-Jun. Supershifted DNA-binding complexes indicative of c-Fos and c-Jun protein-containing complexes are indicated by the arrow head. $F$, mobility of unbound labeled AP-1 oligonucleotide without proteins. 
humans frequently encounter, implies an important role for these kinases in the arterial adaptation to fluctuations in blood pressure. Their activation may also contribute directly to pathologic changes, i.e., smooth muscle cell hypertrophy and/ or proliferation, associated with large artery remodeling that occurs in response to hypertension.

The precise signal responsible for the activation of these kinases during acute hypertension is unclear, but likely involves a direct effect of elevated blood pressure on the arterial wall. There is accumulating evidence that stretching of cultured cells can indeed activate MAP kinases $(12,13,33,34)$ and induce c-fos and c-jun gene expression (35-38). However, agents such as angiotensin II and phenylephrine have also been show to directly activate ERK kinase and induce gene expression in cultured cells (25-27). The complexity of the response is further emphasized by recent studies demonstrating that activation of ERK after stretching of cardiac myocytes is mediated in part by angiotensin II that is secreted from the stretched myocytes $(33,34)$. That an elevation in blood pressure is likely to be the primary stimulus for MAP kinase activation in restrained, phenylephrine- and angiotensin-treated animals is supported by several observations. First, the responses are specific to the vasculature, despite the presence of $\alpha_{1}$-adrenergic and angiotensin receptors in other tissues. Second, the dose-response relationships for angiotensin II-induced elevations in blood pressure and MAP kinase activation are closely correlated. Third, JNK and ERK MAP kinases are equally activated by acute hypertension. It has been demonstrated in vitro that while ERK can be activated by both growth factors and stresses, JNK (also referred to stress-activated protein kinase) is less affected by mitogenic stimuli $(11,14,39)$. Finally, the vasodilator sodium nitroprusside, which prevents increases in blood pressure in response to restraint and hypertensive agents, likewise abrogates the kinase activation by these treatments. These findings support the hypothesis that kinase activation in the arterial wall occurs as a physiologic response to acute hypertension. The mechanical stretch to the arterial wall may be at least partially responsible for this effect. However, we cannot exclude the possibility that angiotensin II and phenylephrine directly contribute to the activation of MAP kinases in the arterial wall through other mechanisms, e.g., growth factor receptors, as both agents can activate ERK in cultured smooth muscle cells (25-27). Supporting this view is the fact that sodium nitroprusside completely prevented the elevation in blood pressure, but did not fully abolish the activation of the kinases (Fig. 5).

Several families of transcription factors and regulatory proteins have been shown to be phosphorylated by ERK and JNK resulting in their activation (39). For example, ERK phosphorylates Elk1/TCF transcription factors which forms a ternary complex with the serum response factor p67 $7^{\mathrm{SRF}}(29,30)$. Phosphorylation enhances complex formation and its binding to the serum response element located in the promoters of stress response genes such as c-fos. JNK was identified based on its ability to phosphorylate the c-Jun onco-protein leading to its enhanced transcriptional activity (40). A more recent report has shown activation of TCF by JNK as well (41). In the present study, we demonstrated that ERK and JNK activation was followed by c-fos and c-jun gene expression, suggesting that such correlation also occurs in vivo.

The activities of both pre-existing and newly synthesized c-Fos and c-Jun proteins are modulated through their phos- phorylation by the MAP kinases. Fos and Jun proteins combine to form stable AP-1 heterodimers, which bind to AP-1 consensus sequences present in numerous genes associated with cell proliferative and hypertrophic responses (42), e.g., $\alpha$-actin (42), myosin light chain (43), TGF- $\beta$ (44), collagenase, endothelin-1 $(45,46)$. Our data support the notion that the activated AP-1 binding complexes in arterial wall contain mainly heterodimers of c-Fos and c-Jun since antibodies directed to either c-Fos or c-Jun significantly altered the mobility of AP-1 binding complexes in supershift analysis (Fig. 8). Activation of AP-1 could lead to significant alterations in the genetic program of smooth muscle cells resulting in phenotypic changes and cell proliferation.

Growth and proliferation of smooth muscle cells has been shown to be associated with a number of vascular disease states including medial hypertrophy in hypertension $(47,48)$, intimal thickening in atherosclerosis $(49,50)$, and restenosis after angioplasty (51). Multiple factors including growth factors, cytokines, mechanical stress, neurotransmitters and hormones are believed to contribute to the processes leading to smooth muscle cell growth (47-51). However, little is known regarding how the stimuli are transduced into a signal to direct gene expression in vivo. Our findings provide evidence for the possible signal transduction pathway through which acute hypertension serves as a stimulus for enhanced gene expression in the arterial wall. Thus, stimulated arterial smooth muscle cells initiate the synthesis of proteins necessary for cell proliferation or for accumulation of extracellular matrix resulting in arterial stiffening.

\section{Acknowledgments}

We thank Dr. J. Woodgett for providing the GST-c-Jun expression vector and Dr. J. Kyriakis for providing protocols and valuable reagents for carrying out the immunocomplex kinase assays.

This work was supported in part by the George H. A. Clowes, Jr. Memorial Research Award of the American College of Surgeons, and a National Institutes of Health grant, NIDDK, DK02064-04 (R. Udelsman).

\section{References}

1. Pickering, T. G. 1988. The study of blood pressure in every day life. In Behavioural Medicine in Cardiovascular Disorders. Elbert, T. and D. Vaitl. editors. John Wiley \& Sons, New York. 71-85.

2. Dworkin, B. 1988. Hypertension as a learned response. In Behavioural Medicine in Cardiovascular Disorders. Elbert, T. and D. Vaitl. editors. John Wiley \& Sons, New York. 27-40.

3. Henry, J. P., and C. E. Grim. 1990. Psychosocial mechanisms of primary hypertension. J. Hypertension. 8:783-793.

4. Folkow, B. 1995. Integration of hypertension research in the era of molecular biology. J. Hypertension. 13:5-18.

5. Dzau, V. J., G. H. Gibbons, R. Morishita, and R. E. Pratt. 1994. New perspectives in hypertension research. Hypertension. 23:1132-1140.

6. Owens, G. K. 1989. Control of hypertrophic versus hyperplastic growth of vascular smooth muscle cells. Am. J. Physiol. 257:H1755-H1765.

7. Nishida, E., and Y. Gotoh. 1993. The MAP kinase cascade is essential for diverse signalling pathways. Trends Biochem. Sci. 18:128-131.

8. Cowley, S., H. Paterson, P. Kemp, and C. J. Marshall. 1994. Activation of MAP kinase kinase is necessary and sufficient for PC12 differentiation and for transformation of NIH 3T3 cells. Cell. 77:841-852.

9. Ruderman, J. V. 1993. MAP kinase and the activation of quiescent cells. Curr. Opin. Cell Biol. 5:207-213.

10. Dérijard, B., M. Hibi, I.-H. Wu, T. Barrett, B. Su, T. Deng, M. Karin, and R. J. Davis. 1994. JNK1: a protein kinase stimulated by UV light and HaRas that binds and phosphorylates the c-Jun activation domain. Cell. 76:10251037.

11. Kyriakis, J. M., P. Banerjee, E. Nikolakaki, T. Dai, E. A. Rubie, M. F. Ahmad, J. Avruch, and J. R. Woodgett. 1994. The stress-activated protein ki- 
nase subfamily of c-Jun kinases. Nature (Lond.). 369:156-160.

12. Yamazaki, T., K. Tobe, E. Hoh, K. Maemura, T. Kaida, I. Komuro, H. Tamemoto, T. Kadowaki, R. Nagai, and Y. Yazaki. 1993. Mechanical loading activates mitogen-activated protein kinase and S6 peptide kinase in cultured rat cardiac myocytes. J. Biol. Chem. 268:12069-12076.

13. Adam, L. P., M. T. Franklin, G. J. Raff, and D. R. Hathaway. 1995. Activation of mitogen-activated protein kinase in porcine carotid arteries. Circ. Res. 76:183-190.

14. Cano, E., and L. C. Mahadevan. 1995. Parallel signal processing among mammalian MAPKs. Trends Biochem. Sci. 20:117-1122.

15. Edwards, D. R. 1994. Cell signalling and the control of gene transcription. Trends Pharmacol. Sci. 15:239-244.

16. Watson, M. H., S. L. Venance, S. C. Pang, and A. S. Mak. 1993. Smooth muscle cell proliferation: expression and kinase activities of $\mathrm{p} 34 \mathrm{cdc} 2$ and mitogen-activated protein kinase homologues. Circ. Res. 73:109-117.

17. Blake, M. J., R. Udelsman, G. J. Feulner, D. D. Norton, and N. J. Holbrook. 1991. Stress-induced heat shock protein 70 expression in adrenal cortex: an adrenocorticotropic hormone-sensitive, age-dependent response. Proc. Natl. Acad. Sci. USA. 88:9873-9877.

18. Xu, Q., D. Li, N. J. Holbrook, and R. Udelsman. 1995. Acute hypertension induces heat shock protein 70 gene expression in rat aorta. Circulation, 92 : $1223-1229$

19. Udelsman, R., M. J. Blake, C. A. Stagg, D. Li, D. J. Putney, and N. J. Holbrook. 1993. Vascular heat shock protein expression in response to stress. $J$. Clin. Invest. 91:465-473.

20. Thomas, S. M., M. DeMarco, G. D’Arcangelo, S. Halegoua, and J. S. Brugge. 1992. Ras is essential for nerve growth factor- and phorbol esterinduced tyrosine phosphorylation of MAP kinases. Cell. 68:1031-1040.

21. Liu, Y., M. Gorospe, C. Yang, and N. J. Holbrook. 1995. Role of mitogen-activated protein kinase phosphatase during the cellular response to genotoxic stress. J. Biol. Chem. 270:8377-8380.

22. Kyriakis, J. M., H. App, X. Zhang, P. Banerjee, D. L. Brautigan, U. R. Rapp, and J. Avruch. 1992. Raf-1 activates MAP kinase-kinase. Nature (Lond.). 358:417-421.

23. Fawcett, T. W., S. L. Sylvester, K. D. Sarge, R. I. Morimoto, and N. K. Holbrook. 1994. Effects of neurohormonal stress and aging on the activation of mammalian heat shock factor 1. J. Biol. Chem. 269:32272-32278.

24. Lee, M., P. Mitchell, and R. Tjian. 1987. Purified transcription factor AP-1 interacts with TPA-inducible enhancer elements. Cell. 49:741-752.

25. Tsuda, T., Y. Kawahara, Y. Ishida, M. Koide, K. Shii, and M. Yokoyama. 1992. Angiotensin II stimulates two myelin basic protein/microtubuleassociated protein 2 kinases in cultured vascular smooth muscle cells. Circ. Res. 71:620-630.

26. Duff, J. L., B. C. Berk, and M. A. Corson. 1992. Angiotensin II stimulates the pp44 and pp42 mitogen-activated protein kinases in cultured rat aortic smooth muscle cells. Biochem. Biophys. Res. Commun. 188:257-264.

27. Thorburn, A. 1994. Ras activity is required for phenylephrine-induced activation of mitogen-activated protein kinase in cardiac muscle cells. Biochem. Biophys. Res. Commun. 205:1417-1422.

28. Schini, V. B., and P. M. Vanhoutte. 1993. Role of the L-arginine-nitric oxide pathway in vascular smooth muscle. Eur. Heart J. 14 (Suppl I):16-21.

29. Gille, H., A. D. Sharrocks, and P. E. Shaw. 1992. Phosphorylation of transcription factor p62 ${ }^{\mathrm{TCF}}$ by MAP kinase stimulates ternary complex formation at c-fos promoter. Nature (Lond.). 358:414-417.

30. Hill, C. S., R. Marais, S. John, J. Wynne, S. Dalton, and R. Treisman. 1993. Functional analysis of a growth factor-responsive transcription factor complex. Cell. 73:395-406.

31. van Dam, H., M. Duyndam, R. Rottier, A. Bosch, L. de Vries-Smits, P. Herrlich, A. Zantema, P. Angel, and A. J. van der Eb. 1993. Heterodimer formation of c-Jun and ATF-2 is responsible for induction of $c$-jun by the 243 amino acid adenovirus E1A protein. EMBO (Eur. Mol. Biol. Organ.) J. 12:479487.

32. Abate, C., L. Patel, F. J. Rauscher III, and T. Curran. 1990. Redox regulation of Fos and Jun DNA-binding activity in vitro. Science (Wash. DC). 249: 1157-1161.

33. Yamazaki, T., I. Komuro, S. Kudoh, Y. Zou, I. Shiojima, T. Mizuno, H. Takano, Y. Hiroi, K. Ueki, K. Tobe, T. Kadowaki, R. Nagai, and Y. Yazaki. 1995. Mechanical stress activates protein kinase cascade of phosphorylation in neonatal rat cardiac myocytes. J. Clin. Invest. 96:438-446.

34. Yamazaki, T., I. Komuro, S. Kudoh, Y. Zou, I. Shiojima, T. Mizuno, H. Takano, Y. Hiroi, K. Ueki, K. Tobe, T. Kadowaki, R. Nagai, and Y. Yazaki. 1995. Angiotensin II partly mediates mechanical stress-induced cardiac hypertrophy. Cir. Res. 77:258-265.

35. Izumo, S., B. Nadal-Ginard, and V. Mahdavi. 1988. Protooncogene induction and reprogramming of cardiac gene expression produced by pressure overload. Proc. Natl. Acad. Sci. USA. 85:339-343.

36. Sadoshima, J-i., L. Jahn, T. Takahashi, T. J. Kulik, and S. Izomo. 1992. Molecular characterization of the stretch-induced adaptation of cultured cardiac cells: An in vitro model of load-induced cardiac hypertrophy. J. Biol. Chem. 267:10551-10560

37. Komuro, I., T. Kaida, Y. Shibazaki, K. Kurabayashi, F. Takaku, and Y. Yazaki. 1990. Streching cardiac myocytes stimulates proto-oncogene expression. J. Biol. Chem. 265:3595-3598.

38. Komuro, I., and Y. Yazaki. 1993. Control of cardiac gene expression by mechanical stress. Annu. Rev. Physiol. 55:55-75.

39. Davis, R. J. 1993. The mitogen-activated protein kinase signal transduction pathway. J. Biol. Chem. 268:14553-14556.

40. Hibi, M., A. Lin, T. Smeal, A. Minden, and M. Karin. 1993. Identification of an oncoprotein- and UV-responsive protein kinases that bind and potentiate the c-Jun activation domain. Genes Dev. 7:2135-2148.

41. Whitmarsh, A. J., P. Shore, A. D. Sharrocks, and R. J. Davis. 1995. Integration of MAP kinase signal transduction pathways at the serum response element. Science (Wash. DC). 269:403-407.

42. Bishopric, N. H., V. V. Jayasena, and K. A. Webster. 1992. Positive regulation of the skeletal alpha-actin gene by Fos and Jun in Cardiac myocytes. $J$. Biol. Chem. 267:25535-25540.

43. Iwaki, K., V. P. Sukhatme, H. E. Shubeita, and K. R. Chien. 1990. $\alpha$ - and $\beta$-adrenergic stimulation induces distinct patterns of immediate early gene expression in neonatal rat myocardial cells. J. Biol. Chem. 265:13809-13817.

44. Kim, S., P. Angel, R. Lafyatis, K. Hattori, K. Y. Kim, M. B. Sporn, M. Karin, and A. B. Roberts. 1990. Autoinduction of transforming growth factor $\beta 1$ is mediated by the AP-1 complex. Mol. Cell. Biol. 10:1492-1497.

45. Lee, M., M. S. Dhahdly, D. Temizer, J. Clifford, M. Yoshizumi, and T. Quertermous. 1991. Regulation of endothelin-1 gene expression by Fos and Jun. J. Biol. Chem. 266:19043-19039.

46. Karin, M. 1995. The regulation of AP-1 activity by mitogen-activated protein kinases. J. Biol. Chem. 270:16483-16486.

47. Lee, R. M. K. W., J. B. Forrest, R. E. Garfield, and E. E. Daniel. 1983. Comparison of blood vessel wall dimensions in normotensive and hypertensive rats by histometric and morphometric methods. Blood Vessels. 20:245-254.

48. Schwartz, S. M., G. R. Campbell, and J. H. Campbell. 1986. Replication of smooth muscle cells in vascular disease. Circ. Res. 58:427-444.

49. Gordon, D., M. A. Reidy, E. P. Benditt, and S. M. Schwartz. 1990. Cell proliferation in human coronary arteries. Proc. Natl. Acad. Sci. USA. 87:46004604.

50. Ross, R. 1993. The pathogenesis of atherosclerosis: a perspective for the 1990s. Nature (Lond.). 362:801-809.

51. Nobuyoshi, M., T. Kimura, H. Ohishi, H. Horuchi, H. Nosaka, H. Hamasaki, H. Yokoi, and K. Koutoka. 1991. Restenosis after percutaneous transluminal coronary angioplasty. J. Am. Coll. Cardiol. 17:433-439. 